\title{
РАЗВИТИЕ КРУПНОГО ГОРОДА ЦЕНТРАЛЬНОЙ РОССИИ: ПРОЯВЛЕНИЕ ЦИКЛИЧНОСТИ ЭВОЛЮЦИОННОГО ПРОЦЕССА
}

\author{
М.Н. Куница
}

Брянский государственный университет имени академика И. Г. Петровского, Россия

Поступила в редакцию 26 февраля 2019 г.

\begin{abstract}
Аннотация: Анализируются процессы социально-экономического развития крупного города с глубокими историческими корнями с позиции концепции цикличности. Выявлены пространственно-временные закономерности его функционирования на примере расположенного в Центральной России модельного объекта - областного центра Брянска как одного из древнейших городов страны, основанного в X веке. Раскрыты особенности трансформации его структуры. Выделены 4 цикла развития процессов, их ветви и стадии, обоснована специфика. Циклы определяют общий тренд развития, ветви отражают направленность, стадии - интенсивность процессов. Выражены «волны» пульсации: 4 главных пика роста активности и 4 ложбины резкого снижения. На современном этапе намечается зарождение нового пятого цикла.
\end{abstract}

Ключевые слова: город, развитие, тренд, закономерность, структура, цикл, ветвь, стадия, оживлениие, подъем, регресс, кризис.

\section{Development of the large city of Central Russia: manifestation of cyclicity of the evolutionary process}

\section{M.N. Kunitsa}

Abstract: The processes of social and economic development of the large city with deep historical «roots» from the position of the cyclicity concept are analyses. The spatial and temporal regularities of its function on the example of the modeling object - located in the Central Russia the Bryansk regional center as one of the oldest cites of the country, which founded in the X century, are defined. The features of the transformation of its structure are discovered. Four cycles of development of the processes, their branches and stages are revealed. Their specific character is grounded in the article. The cycles determine the general trend of the development, the branches reflect the direction, the stages - the intensity of processes. The waves of pulsation are expressed: 4 main peaks of activity growth and 4 hollows of sharp decline. At the modern stage the conception of a new fifth cycle is outlined.

Key words: city, development, trend, regularity, structure, cycle, branch, stage, revival, ascent, regress, crisis.

\section{ВВЕДЕНИЕ}

Развитие городов - многогранный процесс. Особенно сложна эволюция исторических населенных пунктов староосвоенных районов. Значение выявления ее особенностей усиливается в настоящее время трансформацией социально-экономических отношений в стране, системой расселения, ядрами которой выступают города. Одна из общих закономерностей - пульсационно-циклический характер. Диахронический анализ, синтез географических, исторических, социально-эко-

(C) Куница М.Н., 2019 номических исследований нацелены на раскрытие «логики» процесса становления, своеобразия современной ситуации и перспективных направлений функционирования городов. Особенно важно это в контексте реализации политики перехода к их сбалансированному развитию. Усиление внимания федеральной власти к проблемам исторических поселений должно подкрепляться практической деятельностью на региональном и муниципальном уровнях.

\section{ПОСТАНОВКА ПРОБЛЕМЫ}

Город - особый тип сложногенетических природно-социально-производственных систем - се- 
литебная геосистема (СГС) [9]. Она является результатом взаимодействия гетерогенных подсистем - биодемосоциальной, производственно-технической, инфраструктурной, управленческой, природной. Интеграционный характер СГС определяет ее качественную специфичность: полиструктурность, полифункциональность, открытость, динамизм, асинхронность развития подсистем, вещественную и информационную насыщенность «памяти» системы как отражение процессов ее формирования, управляемость. Важная особенность - совмещение городом функций аттрактора и генератора инноваций [3]. Цель данной статьи - выявление и обоснование закономерностей развития города с позиции концепции цикличности. Теория циклично-генетической динамики все более востребована в изучении расселения (Д. Джибс, дифференциальная урбанизация, Т. Кюммель, В. Л. Бабурин, О.В. Грицай, Г.В. Иоффе, А.И. Трейвиш). Активизируется ее применение в исследовании городов (Д. Форрестер, Е.Г. Анимица, Н.И. Горин, А. В. Зорин, А. А. Нещадин, И. Д. Тургель) [2, 10, 23, 24]. Их работы выполнены с разных теоретико-методических позиций. Доминирует анализ экономического жизненного цикла города, усиливается внимание и к другим аспектам - социально-демографической, инновационной цикличности.

В статье представлены результаты комплексного исследования эволюции крупного города с глубокими генетическими корнями, расположенного в староосвоенном районе Центра России. Эволюция понимается в широком смысле как развитие, включающее количественные и качественные изменения систем, эволюционные и революционные стадии [4]. В качестве модельного выбран один из старейших городов страны - Брянск, основанный в 985 году [19]. Конец X - начало XI века Б. Д. Греков и М.Н. Тихомиров выделили как «переломный» этап в истории городского расселения Руси. Выраженная особенность развития - циклический характер. Причины смены циклов - трансформация геополитических и экономических отношений, технологического способа производства, политической и социальной структур, демографических процессов, духовной жизни. Направление развития отражают волны «повышательная» и «понижательная» (по Н. Д. Кондратьеву) или «восходящая» и «нисходящая» ветви, а его интенсивность - их стадии [15]. Восходящую ветвь формируют стадии оживления и роста - подъема. Для них типичны усиление геополитического значения, экономический рост, технологические инновации, социально-политическая активизация общества, повышение численности и уровня жизни населения города. «Пик» - кратковременный «режим сбалансированного развития». После него начинается нисходящая ветвь со стадиями регресса и кризиса. Регресс отличает уменьшение геополитической роли, противоречивость развития экономической и технологической баз (сокращение интенсивности с элементами перестройки), социально-политическая нестабильность, негативные демографические процессы. Кризис сопровождается экономическим и инвестиционным спадом, депопуляцией, социально-политической конфликтностью, поляризацией общества, снижением привлекательности города. «Ложбина» развития - политическая и экономическая стагнация, начало социально-экономической, технологической, демографической перестройки. С генерирования новой «миссии» разворачивается следующий цикл. Смена циклов сопровождается трансформацией структуры города. Ветви цикла хронологически не симметричны. Микроциклы - «колебания» активности процесса.

\section{МАТЕРИАЛЫ И МЕТОДИКА АНАЛИЗА}

Для выявления особенностей эволюционного развития города был проведен комплексный диахронический пространственно-временной анализ. Типы информационных источников - литературные, фондовые, архивные, статистические, картографические, данные селитебных исследований автора. Основными подходами изучения стали историко-генетический, системный и проблемный.

Анализ включал несколько этапов. Первый создание банка информации о развитии города и оценка ее историко-географической достоверности. Второй - определение комплекса «хроноиндикаторов», обеспечивающих выявление тренда функционирования населенного пункта как СГС. «Историческое событие», введенное как понятие историко-географической периодизации [7], было скорректировано для объекта ранга города и учтено в качестве важного реального фактора-индикатора. Оно определяет переход одной или нескольких подсистем в новое состояние, влияет на изменение траектории развития всей СГС. Кроме него комплекс индикаторов образуют: основные (политико-административный статус, численность населения, функциональной тип, тип планировочной структуры) и дополнительные (количественные социально-демографические и экономические) группы. Третий - разработка периодизации разви- 
Цикличность процесса развития Брянска (составлено автором)

\begin{tabular}{|c|c|c|c|c|}
\hline \multirow[t]{2}{*}{ Цикл } & \multirow[t]{2}{*}{ Стадия } & \multicolumn{2}{|c|}{ Датировка } & \multirow{2}{*}{$\begin{array}{l}\text { Длитель- } \\
\text { ность, лет }\end{array}$} \\
\hline & & начало & окончание & \\
\hline \multirow[t]{5}{*}{ Первый } & & конец X в. & середина XIV в. & 380 \\
\hline & 1. Оживление & конец X в. & середина XII в. & 170 \\
\hline & 2. Подъем & середина XII в. & 70-е гг. XIII в. & 130 \\
\hline & 3. Регресс & 80-е гг. XIII в. & 20-е гг. XIV в. & 50 \\
\hline & 4. Кризис & 30-е гг. XIV в. & середина XIV в. & 30 \\
\hline \multirow[t]{5}{*}{ Второй } & & середина XIV в. & начало XVIII в. & 360 \\
\hline & 1. Оживление & середина XIV в. & конец XV в. & 140 \\
\hline & 2. Подъем & начало XVI в. & конец XVI в. & 100 \\
\hline & 3. Регресс & начало XVII в. & конец XVII в. & 90 \\
\hline & 4. Кризис & конец XVII в. & начало XVIII в. & 30 \\
\hline \multirow[t]{5}{*}{ Третий } & & начало XVIII в. & начало XX в. & 200 \\
\hline & 1. Оживление & начало XVIII в. & 40-е гг. XIX в. & 130 \\
\hline & 2. Подъем & середина XIX в. & конец XIX в. & 40 \\
\hline & 3. Регресс & конец XIX в. & начало XX в. & 20 \\
\hline & 4. Кризис & \multicolumn{2}{|c|}{ начало XX в. } & 10 \\
\hline \multirow[t]{6}{*}{ Четвертый } & & начало XX в. & начало XXI в. & 98 \\
\hline & 1. Оживление & 20-е гг. XX в. & 1940 г. & 20 \\
\hline & Микроцикл ВОВ & 1941 г. & 1945 г. & 5 \\
\hline & 2. Подъем & $\begin{array}{c}\text { середина 40-Х гг. } \\
\text { XX в. }\end{array}$ & $\begin{array}{c}\text { середина 70-Х гг. } \\
\text { XX в. }\end{array}$ & 30 \\
\hline & 3. Регресс & $\begin{array}{c}\text { середина 70-Х гг. } \\
\text { ХХ в. }\end{array}$ & 80-е гг. XX в. & 15 \\
\hline & 4. Кризис & 90-е гг. XX в. & начало XXI в. & 28 \\
\hline
\end{tabular}

тия города. Выделены циклы, ветви, стадии. Циклы соответствуют социально-экономическим эпохам, которые обуславливают общий тренд исторической пульсации процессов. Ветви отражают периоды разной направленности и качественной трансформации, стадии - этапы различной интенсивности процессов. Четвертый - диахронический анализ с позиции теории циклов. Он основывался на следующих принципах: синтеза гетерогенной информации; комплексности - сопряженного изучения особенностей функционирования подсистем в контексте сопоставимости их историко-генетических ритмов; системности - анализа развития населенного пункта как СГС; отражения эволюционного тренда выбранными индикаторами; пороговых различий между ветвями, стадиями; относительного внутреннего единства стадий; однородности структуры микроциклов [17].

Эволюционный тренд развития города Брянска. Брянск отличается глубокими генетическими корнями, сложностью процесса становления современной структуры, выраженными системообразующими функциями. Важные особенности - высокий уровень природной контрастности местоположения (размещение в контактной зоне ополья, двух полесских и двух долинных ландшафтов трех физико-географических районов с разным природно-ресурсным потенциалом) и долговременность геополитического эффекта «пограничности» как аттракторы его развития. Длительность функционирования определила «многослойность» природно-селитебно-производственной (ПСП) структуры города, концентрацию в нем $18 \%$ историко-культурного наследия Брянской области. В эволюционном процессе развития Брянска выявлены 4 цикла, 8 ветвей и 16 стадий (таблица).

Цикл первый - древнерусский период раннего феодализма, формирования и развития города как военно-административного центра края, становления его ПСП структуры. В восходящей ветви 2 стадии.

Стадия оживления - этап зарождения города. Брянск - один из древнейших русских городов. Он был создан в конце $\mathrm{X}$ века как опорный военный пункт Киевского княжества для борьбы с вятичами в процессе объединения славянских племен в 
единое государство - Киевскую Русь [16]. Брянск (Дьбрянск, Добрянск, Дебрянск) располагался на возвышенном правобережье реки Десны напротив устья реки Болвы, имел типичную «двухчастную структуру» и развивался как укрепленное городище с торгово-ремесленным посадом - «Чашин Курган» [14]. Его микроположение диктовалось требованиями обороны и выгодным экономикогеографическим положением в месте пересечения двух важных торговых путей (одного из Киева на Оку и Волгу, другого - мимо устья реки Болвы на запад). Впервые Брянск упоминается в Ипатьевской летописи в 1146 году [20]. Он выполнял функции не только военного и хозяйственного центра округи Подеснинья, но и пограничного города Киевской Руси.

Стадия подъема - этап развития города как военно-административного центра во время феодальной раздробленности Киевской Руси. Изменяется микроположение Брянска. После уничтожения городища на Чашином Кургане новое ядро формируется на Покровской и Петровской Горах [12, 20]. Брянск имел структуру, характерную для древнерусских городов. В пределах высокотеррасовой местности размещались детинец, укрепленный окольный город и большая часть посада. Сложность становления местной власти, изменение роли внешних «полюсов влияния» определили вхождение Брянска сначала в состав Вщижского, а затем Чернигово-Северского княжества. Выгодное военно-стратегическое и транспортно-географическое положение способствовало усилению его оборонного, административного, экономического значения в Подесенье. С 1246 года Брянск становится центром самостоятельного Брянского княжества, стольным городом Чернигово-Северской земли вместо разоренного монголами Чернигова [20]. Важный аттрактор - новый статус центра епархии. Возрастает хозяйственный потенциал поселения. Город переживает первый «пик» своего развития. Повышается его геополитическая и социально-экономическая роль на Руси.

Нисходящую ветвь образуют две стадии. $\mathrm{Cma}$ дия регресса - этап развития города как военноадминистративного центра Брянского княжества во время татаро-монгольского нашествия. За право владеть стольным городом боролись Смоленское княжество, Золотая Орда, Великое княжество Литовское [16]. Распространенные в регионе заболоченные полесские ландшафты выполняли по отношению к нему защитную функцию. Брянск не был уничтожен, хотя несколько раз подвергался разорению. Его восстанавливали с сохранением каркаса компактной планировочной структуры, ядро которой располагалось в пределах высокотеррасовой местности. Форпостами поселения становятся Свенский и Петропавловский монастыри. Важный фактор «устойчивости» города - доминанта его военно-административных функций. Однако он начинает терять геополитическое значение, особенно после разграбления татаро-монголами. Активизируется «пульсация» хозяйственного и социального развития. Религиозный аттрактор уже недостаточно эффективно используется властями. К концу этапа роль Брянска как одного из крупных опорных пунктов Руси снизилась.

Цикл заканчивается стадией кризиса. Характерны постоянные междоусобные распри, изменение геополитической и экономической ориентации города вследствие «перехода» его под власть разных княжеских династий, зависимость от Золотой Орды, войны с литовцами, неоднократные мятежи, что ослабило социально-экономический потенциал Брянска.

Цикл второй - период развитого феодализма, функционирования города как военно-стратегического и торгового центра, цикличности в формировании его ПСП структуры. В восходящей ветви 2 стадии.

Стадия оживления - этап развития города как военно-торгового центра во время литовского владычества. В середине XIV века Брянск попадает под власть Литвы. Он теряет политический суверенитет, статус столицы княжества и становится поветовым (уездным) городом [13]. Важной функцией остается оборонная, обусловленная приграничным экономико-географическим положением и наличием укрепленной крепости. Освобождение от татаро-монгольского ига - сильный импульс роста численности населения, развития экономики, активизации торговых связей. Во второй половине XV века между Московским и Литовским Великими княжествами начинается многолетняя борьба за освобождение русских земель. Город с окрестностями неоднократно опустошался и отстраивался. Компактная планировка в целом сохранялась. Усилилось политическое и экономическое тяготение Брянска к Москве.

Стадия подъема - этап развития города как военно-торгового центра Русского государства, «пульсационности» его социально-экономического функционирования. В 1503 году Брянск - значительный военно-стратегический и торговый центр края был юридически включен в состав Рус- 
ского государства [19]. Он становится важным городом на его юго-западном приграничье. Увеличивается численность населения. Усложняются производственные и торговые функции. Расширяется площадь ареала. Ядро поселения включало крепость на Покровской и селитьбу на Петровской Горах. На низких террасах активно развивается посад, состоявший из слобод. Создаются новые монастырские комплексы - Воскресенский, Спасо-Поликарпов, Предтечев-Песоцкий, церкви [20]. В русско-литовских военных конфликтах Брянск разоряли и сжигали, однако он пострадал меньше других городов Подеснинья. Прослеживались два микроцикла - менее выраженный - спада и преобладающий - активизации развития.

Нисходящая ветвь включает две стадии. Cmaдия регресса - этап функционирования города как военно-стратегического центра, доминирования процесса ослабления интенсивности его развития. Брянск являлся важным пограничным оборонным пунктом Русского государства. «Смутное время», непрерывные русско-польские войны, набеги крымских татар, усиление крепостнического гнета и классовой борьбы, голод - факторы, лимитирующие жизнедеятельность в городе. В сложной динамике численности населения доминировало снижение. Резко возросла роль оборонной, но снизилась - производственной и торговой функций. В социальной структуре преобладала «служилая» категория [25]. Уровень благоустройства был низок, в том числе вследствие пожаров. Только в конце XVII века после победы Русского государства над Речью Посполитой Брянск был заново укреплен и отстроен. Развивается не только центр, но и посад, слободы (Затинная, Стрелецкая, Ямская, Зарецкая) [20]. Оживляются торговые связи. Особую роль в этом играет Свенская ярмарка - вторая после Макарьевской по значению в стране. Однако в функционировании города преобладали микроциклы с негативными трендами, обострялся комплекс проблем.

Стадия кризиса в крае развивалась в условиях Северной войны, смут горожан, роста налогов, периодических неурожаев. Характерна неустойчивость тенденций развития, усложнение социально-экономической ситуации. Происходит трансформация военно-стратегического значения города (усиление - снижение). Новые производственные проекты (военное и транспортное судостроение на Брянской верфи) оказались недостаточно эффективны для влияния на функциональный тип города. Изменение роли Свенской ярмарки от рас- цвета до «сужения» обусловило пульсацию важности Брянска как торгового и таможенного пункта, ориентированного на связи Украины с центром страны.

Цикл третий - период кризиса феодализма, зарождения и развития капитализма, функционирования города как торгово-промышленного и транспортного центра, изменения интенсивности формирования его ПСП структуры. Восходящая ветвь включает 2 стадии.

Стадия оживления - этап активизации развития города как торгово-промышленного центра в условиях кризиса феодализма, зарождения капитализма. Вследствие расширения территории России Брянск теряет оборонно-стратегическое значение. Неоднократно меняется его административная принадлежность при устойчивости статуса уездного города. В 1778 году на длительный период он входит в состав Орловского наместничества (позже губернии). Количество жителей с середины XVIII века по 1850 год увеличилось с 4,0 до 9,5 тыс. человек [8, 21]. Стало преобладать экономически активное посадское население [25]. «Выстраивается» новая конкурентная среда. Развивается торговля, изменяются направления связей. Важный «импульс» - рост мануфактурного, а затем и промышленного производства. В 1824 году действовало 5, в 1852 году - 28 в основном небольших фабрик и заводов (канатных, лесопильных, пивоваренных) [13]. Усиливается оборонный «сектор». Выделяется завод «Арсенал» - один из крупнейших производителей артиллеристских орудий в России. Трансформируется функциональное зонирование города. На территории бывшей крепости создается новое административное ядро. Возникают промышленные ареалы. Три нагорных района композиционно соединяет один прибрежный. С утверждения в 1780 году первого генерального плана начинается качественно новый процесс регулирования градостроительства [20].

Стадия подъема - этап активизации развития города как промышленного и транспортного центра в условиях интенсификации капитализма. Довольно быстро росла численность населения: с 13,9 до 21,0 тыс. человек за период 1866-1890 годов $[8,19]$. Реформа 1861 года, стимулировавшая капиталистическое производство, качественное улучшение транспортно-географического положения (включение в железнодорожную сеть страны) стали новыми импульсами социально-экономического развития города. К началу 90-х годов XIX века количество фабрик и заводов увеличилось до 50 
[8]. Основу индустрии составляли металлообработка и машиностроение при существенной роли лесопильного и канатного производств. Брянск становится крупным транспортным и промышленным центром Европейской России [16]. Однако функционированию социальной сферы уделялось недостаточное внимание. Город по-прежнему размещался на возвышенном правобережье реки Десны. На низких террасах левого берега возникают новые ядра его будущих административных районов: транспортно-промышленного поселка Бежица с одним из ведущих в стране Брянским рельсопрокатным, железоделательным и механическим заводом и двух железнодорожных поселков.

Нисходящая ветвь представлена 2 стадиями. Cтадия регресса - этап «пульсационного» социально-экономического развития города. Увеличилось его население (до 30,7 тыс. человек в 1913 году) [20]. Кризис, а затем стагнация экономики, усиление конкуренции, забастовки - негативные факторы функционирования Брянска. Замедлились темпы индустриализации. Начало нового подъема было прервано Первой мировой войной. В конце этапа насчитывалось 80 фабрик и заводов [13]. Основные отрасли - металлообработка и машиностроение, лесопиление, легкая промышленность. Самым крупным предприятием оставался «Арсенал». Развивалась социальная сфера, но уровень благоустройства города был невысок. Усложнялась планировочная структура. Росли экономически ориентированные на него, но еще не вошедшие в его административный состав Бежица и два железнодорожных поселка.

Стадия кризиса - этап экстенсивного функционирования города во время кризиса капитализма, Первой мировой и гражданской войн. Военные действия в стране сдерживали экономическое развитие города. Уровень производства в Брянске к концу этапа по сравнению с 1913 годом упал в 5 раз [13]. Кризис обострился эвакуацией и реэвакуацией предприятий, безработицей, уходом большого количества жителей на фронт, наплывом беженцев, оттоком горожан в сельскую местность. Численность населения все же несколько выросла (до 34,8 тыс. человек в 1920 году) [6]. Территория города увеличилась, в основном вследствие «поглощения» ряда слобод. Однако уровень благоустройства существенно снизился.

Цикл четвертый - период развития города как промышленного и транспортного узла в условиях индустриальной «цивилизации», изменения интенсивности формирования современной ПСП струк- туры. Он отражает «жизнедеятельность» Брянска в XX - начале XXI века в составе СССР - Российской Федерации, отличается сложностью и «сжатостью» процессов, выраженностью микроциклов. Восходящая ветвь представлена 2 стадиями.

Стадия оживления - этап активизации и трансформации функционирования города как транспортно-промышленного центра в условиях восстановления и предвоенного развития хозяйства страны. Значительно увеличилась численность населения: с 47,7 тыс. человек в 1926 году до почти 100 тыс. человек в 1940 [6, 20]. Происходит смена административного статуса Брянска: от центра образованной Брянской губернии (19201929 гг.) до города областного подчинения Западной, а с 1937 года - Орловской областей [1]. Несмотря на сложность процессов развития его индустриальный и транспортный потенциалы быстро наращиваются. Изменяется специализация промышленности. Доминирует машиностроение при существенной роли легкой и пищевой отраслей. Выпуск продукции к концу этапа превысил уровень 1913 года в 10 раз [8]. Усиливается значение Брянска как транспортного узла. Улучшается облик провинциального города. Создается новое городское хозяйство и социальная сфера. Были открыты 2 института, техникумы. Трансформируется планировочная структура из-за присоединения пригородных поселков. Она становится многоядерной. В генеральных планах обосновывается новое зонирование, черты которого прослеживаются и сейчас. Собственно Брянск рассматривался как административно-общественный центр Большого Брянска. Володарский район - зона тяжелой промышленности и транспорта, Фокинский - средней промышленности и вспомогательных предприятий [20]. Развитие города требовало усиления транспортной связи между ними.

Стадия завершается микроциклом Великой Отечественной войны, разрушения и качественного изменения структуры города. С приближением врага осуществлялась эвакуация людей и предприятий. За период оккупации (06.10.1941 - 17.09.1943 гг.) население уменьшилось более чем в 3 раза (до 31,5 тыс. человек) [11]. Было уничтожено $70 \%$ жилого фонда, здания всех заводов, вокзалы, 10 мостов. Сумма ущерба, нанесенного Большому Брянску, составила 10 млрд. руб. [13]. После освобождения начались восстановительные работы. С 1944 года повышается административный статус города. Он становится центром образованной Брянской области. 
Стадия подъема - этап восстановления и интенсивного развития города как административнокультурного центра, транспортно-промышленного узла, активизации формирования его современной ПСП структуры. В 1945 году Брянск был включен в число 15 старейших русских городов, подлежащих первоочередному возрождению. За 5 лет промышленность и городское хозяйство были восстановлены до довоенного уровня [8]. Усиливается его роль как крупного транспортного узла. Интенсивно развивается экономика. Ведущая отрасль специализации - машиностроение, ориентированная на оборонный комплекс. Возрастает значение металлургии, химической, легкой, пищевой индустрии. Крупнейшие заводы - Брянский машиностроительный, автомобильный, дорожных машин, сельскохозяйственных машин, ирригационных машин, сталелитейный, фосфоритный, камвольный комбинат и другие [8, 13]. Объем промышленной продукции к концу этапа превысил уровень 1940 года в 13 раз [18]. Происходит рост и качественное улучшение непроизводственной сферы. Активизация социально-экономического развития и административные преобразования (включение в черту Брянска города Бежица, поселков) способствовали быстрому увеличению числа жителей - до 363,5 тыс. человек в 1975 году [18]. Усложняется территориальное и функциональное зонирование. Утверждаются генеральные планы Брянска как населенного пункта многоядерной планировочной структуры (1946, 1958, 1968 годы). Трансформируется городская система, в которой исторически сложившиеся районы (Советский, Володарский, Фокинский, Бежицкий) развиваются как ее градостроительные единицы, однако еще недостаточно эффективно транспортно взаимосвязанные.

Нисходящую ветвь образуют 2 стадии. Cmaдия регресса - этап «пульсационного» развития города как транспортно-промышленного узла при доминировании тренда снижения интенсивности процессов, усложнения его ПСП структуры. Смена социально-экономических тенденций функционирования Брянска (рост - уменьшение активности) определялась трансформацией политического и экономического курсов развития СССР и региональными факторами. Продолжалось увеличение населения города (до 475,3 тыс. человек в 1991 году), но на фоне «сужения» ежегодного прироста [27]. Начинается сокращение трудового потенциала. К концу этапа в целом сформировалась отраслевая структура, типичная для 4 волны
Н. Д. Кондратьева с преобладанием транспортного и точного машиностроения. Важную роль играли металлургия, химическая, легкая промышленности. Однако углубляется комплекс проблем. Одна из ведущих - недостаточное финансирование производственной и непроизводственной сфер. В промышленности в 80-е годы активизируются негативные тенденции замедления роста, а во время «перестройки» начинает меняться ее структура. Фактор сдерживания неблагоприятных трендов - повышение значения города как крупного транспортного узла. Происходит переход к стагнации функционирования социальной сферы и городского хозяйства. Планировочная структура Брянска остается многоядерной. Действует генеральный план 1968 года с изменениями 1973 и 1977 годов [20]. Четыре района продолжают функционировать как градостроительные единицы со сложной транспортной интеграцией в городскую систему. Формируются многие особенности современного зонирования города.

Стадия кризиса - этап трансформации социально-экономического потенциала и ПСП структуры города в условиях становления нового государства (Российской Федерации) и типов социально-экономических отношений. В хроноструктуре цикла длительность данной стадии достаточно велика, что определяется сложностью взаимодействия гетерогенных процессов: геополитических (распад СССР с возникновением Российской Федерации), экономических (формирование рыночной экономики, экономические «волны», перестройка систем территориального разделения труда), социально-демографических (демографические «волны»). Кризис 90-х годов ХХ века, как в целом в стране, сочетал признаки системного, циклического и структурного [22]. В начале XXI века на наметившийся позитивный тренд «наложились» мировой и российский кризисы, санкции США и Европейского Союза.

Характерна трансформация социально-экономического развития Брянска. Выражены негативные изменения. С 1995 года устойчиво сокращается демографический потенциал города - до 423,98 тыс. человек в начале 2018 года (на 10,8\%) вследствие постоянной естественной и длительной миграционной убыли. Произошел переход к индустриально-сервисному типу экономики. Данный тренд - свидетельство не столько формирования постиндустриальной структуры, сколько падения материального производства. Проблемность функционирования градообразующих отраслей и 
непроизводственной сферы, недостаток инвестиций - индикаторы неблагоприятной социально-экономической ситуации. Специализация города - машиностроение, оборонно-промышленный, транспортно-логистический комплексы. Процесс концентрации определил повышение роли Брянска в хозяйстве области. Однако интенсивность агломерирования невысока. В перестройке эволюционного «хода» урбанизации преобладают стадии поляризационного разворота. Усложняется территориальное и функциональное зонирование Брянска. Выделяются несколько ландшафтно-планировочных районов. Пойменно-рекреационный используется экстенсивно, высокопойменный и частично низкотеррасовый сформировался как производственно-транспортный, склоновый - рекреационно-селитебный. Террасовый отличается преобладанием селитебных, плакорно-междуречный - селитебных и производственных зон. Общественно-деловые зоны размещены дискретно. На повышение качества градостроительной среды многоядерного города нацелен новый генеральный план.

Сейчас прослеживаются положительные социально-экономические тенденции. Однако «позитив», особенно демографический и инвестиционный еще неустойчив. Важные направления преодоления системных проблем - реализация политики импортозамещения, интенсификация инновационного сектора. Планируется стимулирование развития города как полюса роста, специализированного на машиностроительном и транспортно-логистическом комплексах межрегионального российского и международного значения [5]. Вызревают предпосылки перехода к новому циклу.

\section{ВЫВОДЫ}

Брянск - один из древнейших городов России. Длительность и сложность его функционирования определила неоднократную трансформацию структуры, историческую «многослойность». Одна из ведущих закономерностей эволюционного тренда развития Брянска как города с глубокими генетическими корнями - цикличность социально-экономических процессов. Наблюдается их ускорение и хронологическое «сжатие»: I цикл - 380 лет, II цикл - 360 лет, III цикл - 200 лет, IV цикл - 98 лет. Различна продолжительность ветвей: восходящая более долговременна, чем нисходящая. Выделены «волны» пульсации: 4 главных пика роста активности и 4 ложбины резкого снижения. Для XX-начала XXI века характерно уменьшение ин- тенсивности пульсации при усложнении ее структуры. Каждый цикл обеспечивает переход на новый виток развития. На современном этапе намечается зарождение пятого цикла. Выявление закономерностей цикличности - необходимое историко-географическое «звено» комплексного анализа социально-экономического развития населенного пункта, оценки эффективности современных направлений и обоснования перспектив его функционирования. Крупные города можно рассматривать и как специфические геоинформационные системы процесса эволюции сети расселения региона, ядрами которой они являются. Данный научный подход особо значим при исследовании староосвоенных районов.

\section{СПИСОК ЛИТЕРАТУРЫ}

1. Административно-территориальное деление Брянского края за 1916-1985 годы. - Тула : Приокское книжное издательство, 1987. - Т. 2. - 326 с.

2. Анимица Е. Г. Исследование эволюции города: от зарождения, просперити к депрессии (на примере монопрофильного города) / Е. Г. Анимица, Н. В. Сбродова, И. В. Ивлева // Известия Уральского государственного экономического университета. - 2011. - № 2. C. $41-46$.

3. Бабурин В. Л. Инновационные циклы в российской экономике / В. Л. Бабурин. - Москва : УРСС, 2010. $-144 \mathrm{c}$.

4. Большая Российская энциклопедия. - URL : http: //www.bigenc.ru.

5. Брянская городская администрация. - URL : http: //www.bga32.ru. $540 \mathrm{c}$.

6. Брянская губерния в цифрах. - Брянск, 1927. -

7. Вампилова Л. Б. Исторические события и их географические следствия / Л. Б. Вампилова // Вестник Санкт-Петербургского университета. - 2006. - Вып. 4. - C. 116-121.

8. Волохов В. П. Брянск. Очерк прошлого и настоящего одного из старейших русских городов / В. П. Волохов. - Тула : Приокское книжное издательство, 1968. $-191 \mathrm{c}$.

9. Воропай Л. И. Селитебные геосистемы физикогеографических районов Подолии / Л. И. Воропай, М. Н. Куница. - Черновцы : Издательство ЧГУ, 1982. $90 \mathrm{c.}$

10. Горин Н. И. К вопросу о цикличности развития городов: основные положения и закономерности / Н. И. Горин, А. А. Нещадин // Общество и экономика. - 2011. - № 2. - С. 156-176.

11. Именной список учащихся, 1900-1910 гг. // Государственный архив Брянской области. Ф. 31. Оп. 1. Д. 1. Л. 184. 
12. Гурьянов В. Н. Новые данные о древнерусском Брянске / В. Н. Гурьянов // Из истории Брянского края. - Брянск, 1995. - С. 52-56.

13. Дозорцев С. С. Брянск: Историко-экономический очерк / С. С. Дозорцев, М. С. Дозорцев. - Тула : Приокское книжное издательство, 1986. - 175 с.

14. Заверняев Ф. М. Отчет об археологических исследованиях средневекового селища в Бежицком районе г. Брянска и урочище Чашин Курган / Ф. М. Заверняев // Архив ИА РАН. Р-1. № 7939.

15. Кондратьев Н. Д. Избранные сочинения / Н. Д. Кондратьев. - Москва : Экономика, 1993. - 543 с.

16. Крашенинников В. В. Взгляд через столетия / В. В. Крашенинников. - Тула : Приокское книжное издательство, 1990. - 272 с.

17. Куница М. Н. Цикличность развития сети поселений в староосвоенных регионах / М. Н. Куница // Вестник Московского университета. Серия 5. География. - 2012. - № 2. - С. 65-71.

18. Народное хозяйство Брянской области. 19711975 годы : статистический сборник. - Тула : Приокское книжное издательство, 1977. - 120 с.

19. Населенные пункты Брянского края. Энциклопедический словарь. - Брянск : Десяточка, 2010. - 402 с.

20. Свод памятников архитектуры и монументального искусства России: Брянская область. - Москва : Наука, 1998. - 640 c.

21. Соколов В. Брянск / В. Соколов, Б. Шавырин. Брянск : Брянский рабочий, 1952. - 40 с.

22. Трейвиш А. И. Город, район, страна и мир. Развитие России глазами страноведа / А. И. Трейвиш. Москва : Новый хронограф, 2009. - 372 с.

23. Тургель И. Д. Теоретико-методологические аспекты исследования жизненного цикла города / И. Д. Тургель // Научный вестник Уральской академии государственной службы: политология, экономика, социология, право. - 2008. - № 4. - С. 94-104.

24. Форрестер Дж. Динамика развития города / Дж. Форрестер. - Москва : Прогресс, 1974. - 287 с.

25. Цырульников Д. Е. Город Брянск (социальноэкономическое развитие в конце XVII - первой четверти XVIII веков) / Д. Е. Цырульников. - Брянск : Ладомир, 2009. - 168 с.

\section{REFERENCES}

1. Administrativno-territorial'noe delenie Bryanskogo kraya za 1916-1985 gody. - Tula : Priokskoe knizhnoe izdatel'stvo, 1987. - T. 2. - $326 \mathrm{~s}$.

2. Animitsa E. G. Issledovanie evolyutsii goroda: ot zarozhdeniya, prosperiti k depressii (na primere monoprofil'nogo goroda) / E. G. Animitsa, N. V. Sbrodova, I. V. Ivleva // Izvestiya Ural'skogo gosudarstvennogo ekonomicheskogo universiteta. - 2011. - № 2. - S. 41-46.

3. Baburin V. L. Innovatsionnye tsikly v rossiyskoy ekonomike / V. L. Baburin. - Moskva : URSS, 2010. - 144 s.

4. Bol'shaya Rossiyskaya entsiklopediya. - URL: http: //www.bigenc.ru.
5. Bryanskaya gorodskaya administratsiya. - URL: http: //www.bga32.ru.

6. Bryanskaya guberniya v tsifrakh. - Bryansk, 1927. $-540 \mathrm{~s}$.

7. Vampilova L. B. Istoricheskie sobytiya i ikh geograficheskie sledstviya / L. B. Vampilova // Vestnik SanktPeterburgskogo universiteta. - 2006. - Vyp. 4. - S. 116-121.

8. Volokhov V. P. Bryansk. Ocherk proshlogo i nastoyashchego odnogo iz stareyshikh russkikh gorodov / V. P. Volokhov. - Tula : Priokskoe knizhnoe izdatel'stvo, 1968. - $191 \mathrm{~s}$.

9. Voropay L. I. Selitebnye geosistemy fiziko-geograficheskikh rayonov Podolii / L. I. Voropay, M. N. Kunitsa. - Chernovtsy : Izdatel'stvo ChGU, 1982. - 90 s.

10. Gorin N. I. K voprosu o tsiklichnosti razvitiya gorodov: osnovnye polozheniya i zakonomernosti / N. I. Gorin, A. A. Neshchadin // Obshchestvo i ekonomika. - 2011. № 2. - S. 156-176.

11. Imennoy spisok uchashchikhsya, 1900-1910 gg. // Gosudarstvennyy arkhiv Bryanskoy oblasti. F. 31. Op. 1. D. 1. L. 184.

12. Gur'yanov V. N. Novye dannye o drevnerusskom Bryanske / V. N. Gur'yanov // Iz istorii Bryanskogo kraya. - Bryansk, 1995. - S. 52-56.

13. Dozortsev S. S. Bryansk: Istoriko-ekonomicheskiy ocherk / S. S. Dozortsev, M. S. Dozortsev. - Tula : Priokskoe knizhnoe izdatel'stvo, 1986. - $175 \mathrm{~s}$.

14. Zavernyaev F. M. Otchet ob arkheologicheskikh issledovaniyakh srednevekovogo selishcha v Bezhitskom rayone g. Bryanska i urochishche Chashin Kurgan / F. M. Zavernyaev // Arkhiv IA RAN. R-1. № 7939.

15. Kondrat'ev N. D. Izbrannye sochineniya / N. D. Kondrat'ev. - Moskva : Ekonomika, 1993. - 543 s.

16. Krasheninnikov V. V. Vzglyad cherez stoletiya / V. V. Krasheninnikov. - Tula : Priokskoe knizhnoe izdatel'stvo, 1990. - $272 \mathrm{~s}$.

17. Kunitsa M. N. Tsiklichnost' razvitiya seti poseleniy v staroosvoennykh regionakh / M. N. Kunitsa // Vestnik Moskovskogo universiteta. Seriya 5. Geografiya. - 2012. № 2. - S. 65-71.

18. Narodnoe khozyaystvo Bryanskoy oblasti. 19711975 gody : statisticheskiy sbornik. - Tula : Priokskoe knizhnoe izdatel'stvo, 1977. - $120 \mathrm{~s}$.

19. Naselennye punkty Bryanskogo kraya. Entsiklopedicheskiy slovar'. - Bryansk : Desyatochka, 2010. - 402 s.

20. Svod pamyatnikov arkhitektury i monumental'nogo iskusstva Rossii: Bryanskaya oblast'. - Moskva : Nauka, 1998. - $640 \mathrm{~s}$.

21. Sokolov V. Bryansk / V. Sokolov, B. Shavyrin. Bryansk : Bryanskiy rabochiy, 1952. - $40 \mathrm{~s}$.

22. Treyvish A. I. Gorod, rayon, strana i mir. Razvitie Rossii glazami stranoveda / A. I. Treyvish. - Moskva : Novyy khronograf, 2009. - 372 s.

23. Turgel' I. D. Teoretiko-metodologicheskie aspekty issledovaniya zhiznennogo tsikla goroda / I. D. Turgel' // Nauchnyy vestnik Ural'skoy akademii gosudarstvennoy 
sluzhby: politologiya, ekonomika, sotsiologiya, pravo. 2008. - № 4. - S. 94-104.

24. Forrester Dzh. Dinamika razvitiya goroda / Dzh. Forrester. - Moskva : Progress, 1974. - 287 s.

Куница Марина Николаевна

кандидат географических наук, доцент кафедры географии, экологии и землеустройства Брянского государственного университета имени академика И. Г. Петровского, г. Брянск, т. 8(4832) 66-64-55(1145), 66-68-16, E-mail: geodem@mail.ru
25. Tsyrul'nikov D. E. Gorod Bryansk (sotsial'no-ekonomicheskoe razvitie v kontse XVII - pervoy chetverti XVIII vekov) / D. E. Tsyrul'nikov. - Bryansk : Ladomir, 2009. $-168 \mathrm{~s}$.

Kunitsa Marina Nikolayevna

Candidate of Geographical Sciences, Associate Professor of the Department of geography, ecology and land management, Bryansk State Academician I. G. Petrovskiy University, Bryansk, tel. 8(4832) 66-64-55(1145), 66-68-16, E-mail: geodem@mail.ru 